\title{
Effect of Wire Supports on Pod Yield of Winged Beans (Psophocarpus tetragonolobus (L.) DC. ${ }^{1,2}$
}

\author{
R. del Valle, Jr., M. A. Lugo-López and T. W. Scott ${ }^{3}$ \\ ABSTRACT
}

An experiment with winged beans ( Psophocarpus tetragonolobus (L.) (DC.) was conducted in a Torres clay (Plinthic Palehumults) to evaluate the performance of WB 21-8 and WB 10-3, and the effect of using wire supports on growth and development, fresh pod yield and tuber production.

Without wire supports, there were no differences between cultivars either in growth and development or in fresh pod yields. There was, however, a highly significant difference between cultivars when both were grown with wire supports. A significant difference between yields of plants with and without wire supports within cultivar WB 21-8 was evident, while no differences were recorded for cultivar WB 10-3. The interaction of cultivars and use of wire supports was significant.

Fresh pod yields were consistently low for both cultivars when supports were omitted, probably due to pod rot as result of the high soil humidity during pod growth. A field-wide average of $5.7 \mathrm{t} /$ ha was obtained from only three harvests.

There were no significant differences in protein content between treatments. A mean protein content (dry weight basis) of $20 \%$ was recorded. Tuber samples (irrespective of cultivar) had a mean protein content of $10 \%$.

\section{INTRODUCTION}

The winged bean (Psophocarpus tetragonolobus (L.) D.C.) (fig. 1), a little known edible tropical legume grown mainly in Papua, New Guinea, and southeast Asia, seems to be a promising crop for the humid tropics, where protein deficiency is common. Its great ability to grow well under humid conditions, and its high protein content, are among the factors that make this crop so attractive. The green pods, leaves, and seeds are rich in protein and vitamins, and the tuberous roots (on such cultivars which produce them) are probably the richest in protein among known edible root crops. It has been reported that the pod, on a dry weight basis, has a protein content of approximately $20 \%$, while the seeds average about $34 \%$ protein, with a $17 \%$ oil content (4). The leaves are also edible

${ }^{1}$ Manuscript submitted to Editorial Board March 8, 1979.

${ }^{2}$ Joint contribution from the Agricultural Experiment Station, University of Puerto Rico, Río Piedras, P.R., and the Department of Agronomy, Cornell University, Ithaca, N. $\mathrm{Y}$. This study was part of the investigations supported by USAID under research contractta-c-1104.

${ }^{3}$ Assistant Agronomist, Agricultural Experiment Station, University of Puerto Rico, Rio Piedras, P. R., Professor and Soil Scientist (Ret., former Consultant, Cornell University) Agricultural Experiment Station, Mayagüez Campus, University of Puerto Rico, Río Piedras, P.R., and Professor of Soil Science, Cornell University, Ithaca, N. Y. Thanks are given to Dr. Franklin W. Martin, Horticulturist and Officer in Charge, Mayagüez Institute of Tropical Agriculture, (SEA-USDA) for supplying the seed. 
as a salad. The crop grows well in the wet tropics, is highly resistant to most pests and diseases and is very productive (3). Winged bean plants grow vigorously and develop extensive root systems. Comparable with other edible legumes, the winged bean plants appear to have more and larger nodules on their roots $(2,4,6)$.

Not much work with the winged bean has been done in Puerto Rico. Some limited research has been carried out at the Mayagüez Institute of Tropical Agriculture and at the Agricultural Experiment Station of the University of Puerto Rico $(2,3,5)$, since 1974. The greatest potential for this crop appears to be as a garden vegetable or small-scale high intensity production. This is so because the vines need staking and are indetermi-

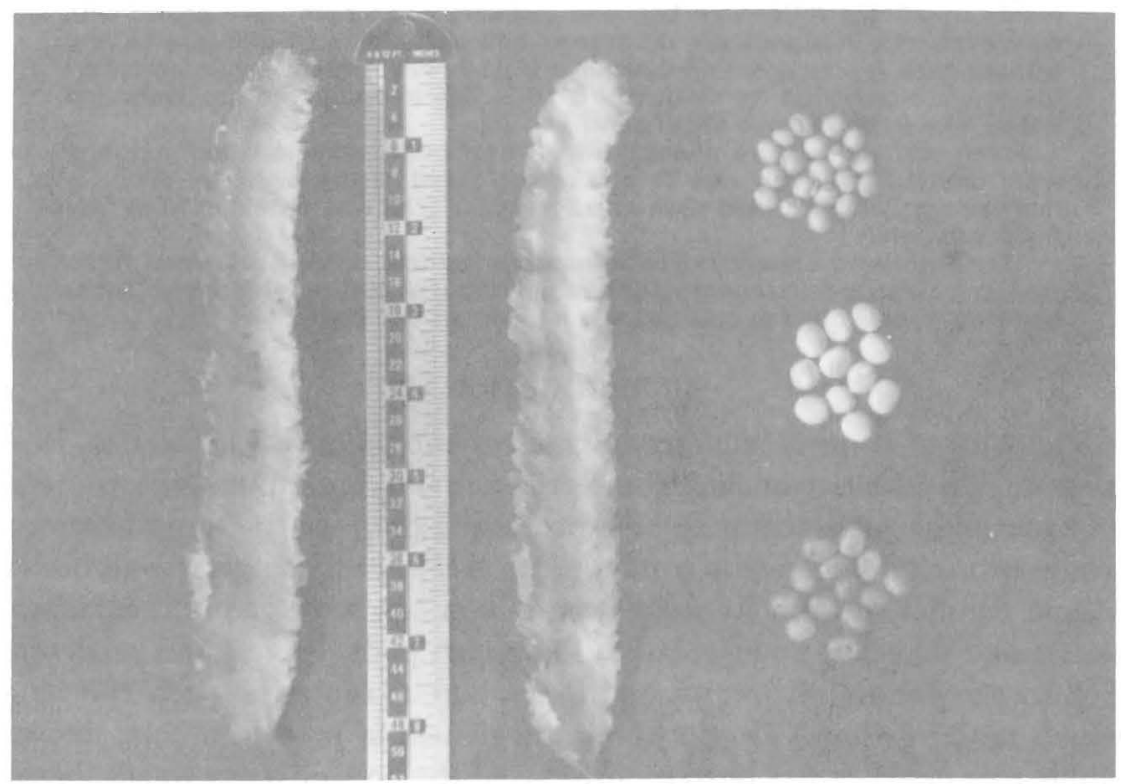

FIG. 1.-Pods and beans of the winged bean.

nate, bearing over a long period of time, requiring regular, periodic picking (3). Some cultivars produce edible, high-protein tuberous roots. For the production of tuberous roots no supports are needed (6).

The objective of the work herein reported was to evaluate the performance of two winged bean cultivars and the effect of wire supports on their growth, development, tuber production, and fresh pod yields.

\section{MATERIALS AND METHODS}

The experiment was conducted at Cidra, Puerto Rico, $450 \mathrm{~m}$ above mean sea level, in Torres clay, an Ultisol, (Plinthic Palehumults, clayey, oxidic, isohyperthermic). Selected chemical properties of the soil are 
shown in table 1. The experiment was planted July 19, 1977, and terminated November 30 , some 4.4 months after planting. The soil is relatively poor in inherent fertility, as reflected by the low $\mathrm{CEC}, \mathrm{Ca}, \mathrm{Mg}$ and $\mathrm{K}$ values, while it is relatively high in Al. In addition, it is relatively low in $\mathrm{P}$, strongly acid and relatively high in organic matter.

Mean summer maximum and minimum temperature at Cidra are approximately 29 and $21^{\circ} \mathrm{C}$, respectively. Mean winter maximum and minimum are approximately $3^{\circ} \mathrm{C}$ lower than in the summer. Solar radiation ranges from an average of 300 langleys/day in winter to 500 langleys/day in summer. Mean yearly precipitation is between 1,650 and $20,000 \mathrm{~mm} /$ year, with only two months (February and March) receiving less than $100 \mathrm{~mm} / \mathrm{month}$. Evaporation from a clas A pan in summer is approximately $5 \mathrm{~mm} /$ day (1).

Plots were $3.7 \times 3.0 \mathrm{~m}$ with subplots of $1.8 \times 3.0 \mathrm{~m}$. Each main plot consisted of 6 rows spaced $61 \mathrm{~cm}$ apart. Plants within the row were spaced

TABLE 1.-Selected chemical properties of Torres clay

\begin{tabular}{|c|c|c|c|c|c|c|c|c|c|c|}
\hline \multirow{2}{*}{ Soil depth } & \multirow{2}{*}{$\mathrm{pH}^{1}$} & \multirow{2}{*}{ O.M. } & \multirow{2}{*}{$\mathrm{Mn}^{2}$} & \multirow{2}{*}{$\mathrm{P}^{3}$} & \multirow{2}{*}{ CEC } & \multicolumn{4}{|c|}{ Exchangeable cations } & \multirow{2}{*}{$\underset{\text { saturation }}{\mathrm{Al}}$} \\
\hline & & & & & & $\mathrm{Ca}$ & $\mathrm{Mg}$ & $\mathrm{K}$ & $\mathrm{Al}^{4}$ & \\
\hline $\mathrm{Cm}$ & & $\%$ & \multicolumn{2}{|c|}{$P / m$} & \multicolumn{5}{|c|}{$\mathrm{Meq} / 100 \mathrm{~g}$} & $\%$ \\
\hline $0-15$ & 4.7 & 4.25 & 87 & 5.5 & 13.0 & 2.15 & 0.65 & .78 & 3.15 & 47 \\
\hline $15-30$ & 4.8 & 2.30 & 74 & - & 10.6 & 1.75 & 0.34 & .55 & 3.37 & 56 \\
\hline $30-60$ & 4.6 & 0.88 & 23 & - & 9.8 & 2.02 & 0.42 & .40 & 4.03 & 59 \\
\hline $60-90$ & 4.7 & 0.42 & 0 & - & 9.7 & 2.36 & 0.49 & .19 & 4.10 & 57 \\
\hline $90-120$ & 4.6 & 0.35 & 0 & - & 9.7 & 2.07 & 0.45 & .21 & 4.94 & 64 \\
\hline
\end{tabular}

' $\mathrm{H}_{2} \mathrm{O}$ :soil ratio of $2: 1$.

${ }^{2} \mathrm{CEC}, \mathrm{Mn}$ and $\mathrm{K}$ determined with a $\mathrm{NH}_{4} \mathrm{OAc}(\mathrm{pH} 7.0)$ extracting solution.

${ }^{3}$ Bray No. 2.

${ }^{4} \mathrm{Ca}, \mathrm{Mg}$ and $\mathrm{Al}$; equilibrium concentration $10 \mathrm{~g}$ soil: $100 \mathrm{ml} 1 \mathrm{~N} \mathrm{KCl}$.

$61 \mathrm{~cm}$ apart with 5 plants to the row and 30 in the main plot. Thus, each subplot had 3 rows with a total of 15 plants.

A split-plot design with four treatments replicated four times was used. The cultivars were the main treatment while wire supports vs no supports were the subtreatments.

Two winged bean cultivars were used: WB 21-8 and WB 10-3. The cultivars can best be described as follows (3):

WB 21-8: Better known by the name of TINGE. Average length of the pods is $19 \mathrm{~cm}$; they are rather flat, straight, small, with smooth wings bordered with purple. It flowers the year-round and is a high yielder.

WB 10-3; Known by the name of MARIPOSA. It bears pods of an average length of $33 \mathrm{~cm}$. The pods are straight and undulate with heavy wings of green with purple borders. In Puerto Rico it flowers only during the winter and is a high yielder. 
Two metal posts $1.82 \mathrm{~m}$ high were placed at the ends of the rows. There were four posts per plot (2 within the sub-plot.). A strong wire was strung over the row between anchor posts placed at the ends of the row. Between anchor posts the wire was supported by posts at a height of $.91 \mathrm{~m}$ above the top of the soil. A strong twine was tied loosely at the base of each plant. The strings between the wires allowed for a row of plants to grow in such a way that the pods could hang below the strings, thus facilitating picking.

No chemical weed control was used. Hoe weeding was done when needed. A total of $1,120 \mathrm{~kg} / \mathrm{ha}$ of a 10-10-10 analysis $+90 \mathrm{~kg} / \mathrm{ha}$ of $\mathrm{Mg}$ as $\mathrm{MgSO}_{4} \cdot 7 \mathrm{H}_{2} \mathrm{O}$ (Epsom salt) was applied to the young plants 2 mo after sowing, when they were flowering.

Pod (fresh green pods) and tuberous root samples were taken on November 1 and 20, and analyzed for protein content. Harvesting was initiated on November 17 and 30, 1977, respectively. Data were taken on fresh pod yield and protein content (dry weight basis).

\section{RESULTS AND DISCUSSIONS}

Plant emergence was very slow in both cultivars, with an average of 14 days for the plants to emerge. Perhaps this delay was influenced by lack of sufficient soil moisture at planting time. A total of only $58 \mathrm{~mm}$ of rainfall was recorded as of July 28, 1977 . No additional rainfall was registered during that month. Crop growth was slow during the first 3 weeks after planting; however, once established, plants grew vigorously. No differences in growth and development were observed between cultivars.

Heavy rainfall $(857 \mathrm{~mm})$ was recorded from the time of planting until the last harvest. Of a total of $857 \mathrm{~mm}, 500$ were recorded during November 1977. As a result of the heavy rainfall, a considerable growth of weeds required frequent weedings.

No major pest or disease was evident during the first 3 mo of growth, but during November there was a heavy infestation of the sugarcane beetle (Diaprepes abreviatus L.), eating pods and leaves. Also rot damage was observed in the plots without wire supports. Effective control of this pest was achieved with two sprays of Diazinon AG-500 E. C. ${ }^{4}$ at the rate of $9.3 \mathrm{~L} / \mathrm{ha}$. No attempt was made to control pod rot; instead, the growing vines with pods were raised by hand from the soil surface and placed on top of the leaves.

\footnotetext{
${ }^{4}$ Trade names in this publication are used only to provide specific information. Mention of a trade name does not constitute a warranty of equipment or materials by the Agricultural Experiment Station of the University of Puerto Rico, nor is this mention a statement of preference over other equipment of materials.
} 
TABLE 2.-Effect of wire supports vs. no supports on fresh pod yield of two winged bean cultivars

\begin{tabular}{lccc}
\hline \multirow{2}{*}{ Cultivar } & Mean yield & \multicolumn{2}{c}{ Yield under indicated treatment } \\
\cline { 3 - 4 } & & Supports & No supports \\
\hline WB $21-8$ & $6.8 \mathrm{a}$ & $9.3 \mathrm{a}$ & $4 /$ ha \\
WB $10-3$ & $4.6 \mathrm{a}$ & $5.3 \mathrm{~b}$ & $4.3 \mathrm{~b}$ \\
\hline
\end{tabular}

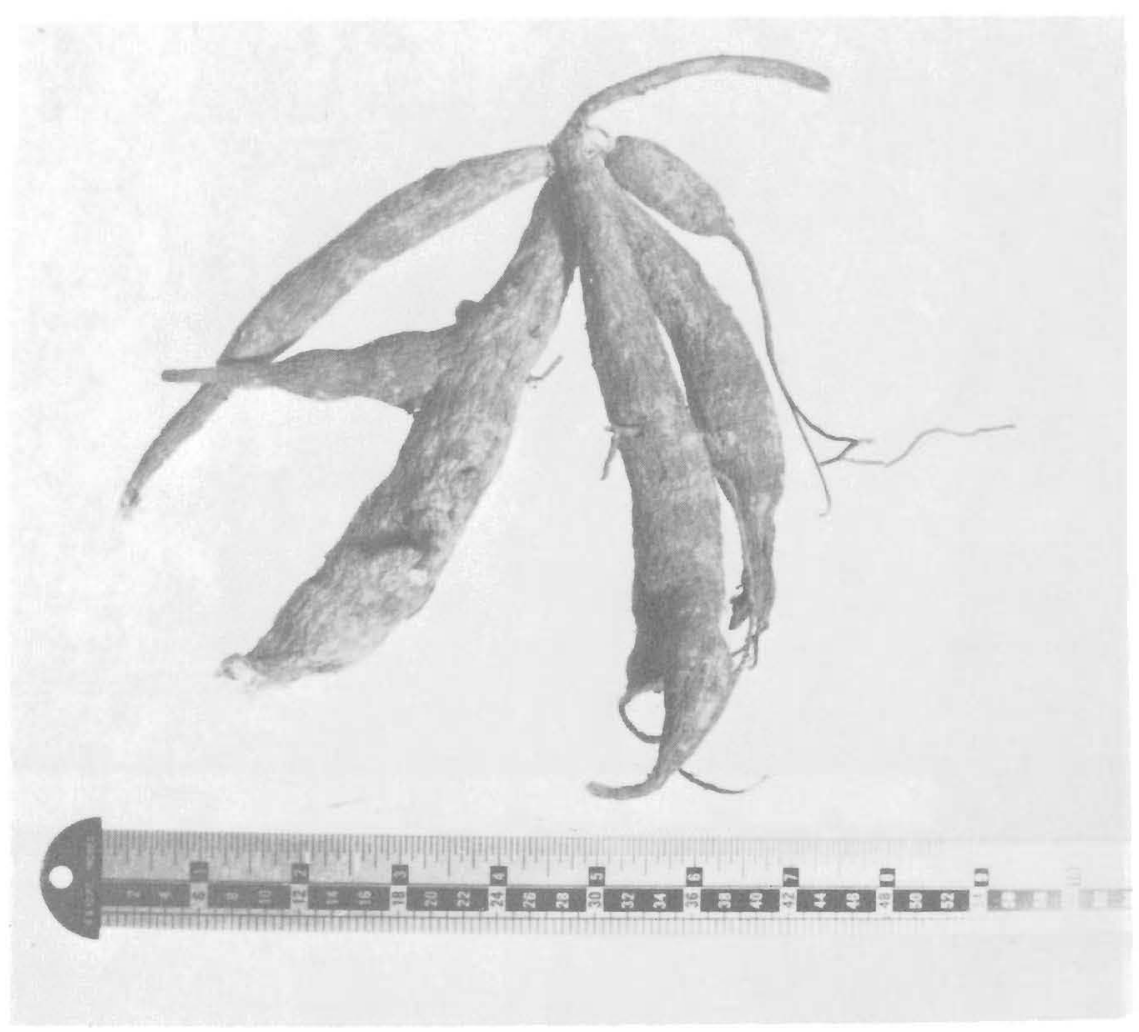

FIG. 2.-Winged bean tubers.

There were no significant differences in protein content between treatments. A mean protein content of $20 \%$ was recorded.

Table 2 shows the fresh pod yields. There were no significant differences between the cultivars. There was, however, a highly significant difference (1\% level) between the cultivars within sub-treatment 1 (supports) and significant differences between the sub-treatments in cultivar WB 21-8. The interaction of treatments $\times$ sub-treatments was significant 
at the $5 \%$ level. No differences were evident between the sub-treatments (wire supports vs. no supports) in cultivar WB 10-3. A field-wide average of $5.7 \mathrm{t} / \mathrm{ha}$ was obtained with only three pickings. This can be considered a good yield in Puerto Rico. Fresh pod yields of $2.8 \mathrm{t} /$ ha were recorded by Pérez-Escolar et al. (5), also in an Ultisol (Humatas series) at Corozal, Puerto Rico.

No data on tuber yields could be recorded because of damage by cattle

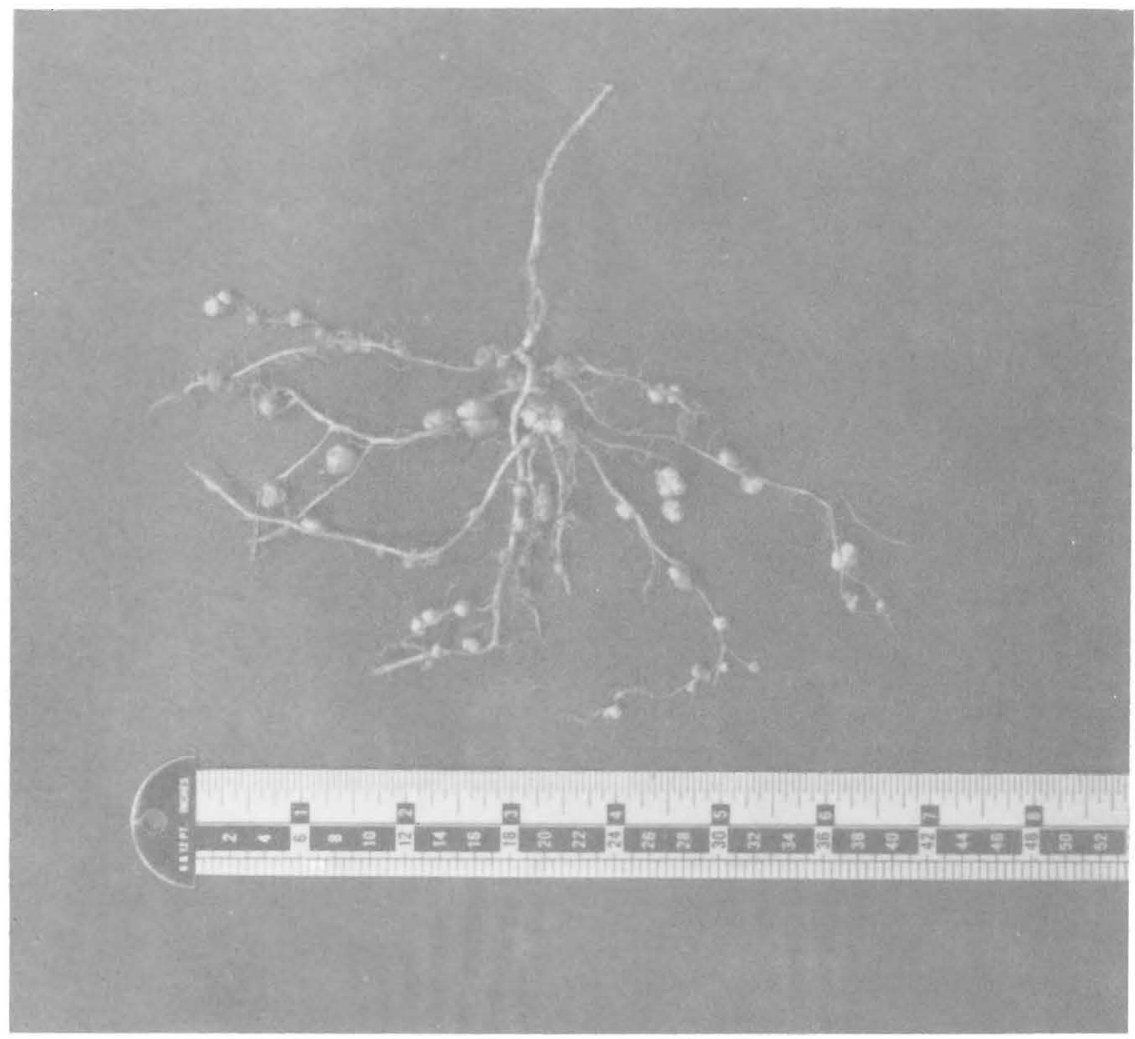

FIG. 3.- Root nodules of the winged bean.

from an adjoining pasture which ate the plants almost to their roots after the last pod picking. However, observations made afterwards showed small tubers (fig. 2), as well as a great number of nodules in the roots (fig. $3)$. There did not seem to be any difference in root yield between plants from the different treatments (wire supports vs. no supports).

The tuber samples (irrespective of cultivar) taken after harvesting revealed a mean protein content of $10 \%$ (dry weight basis). Data available from the National Academy of Science (6) reports a protein content, wet 
weight basis, of 12 to $15 \%$, representing more than $20 \%$ dry weight basis.

These results confirm previous data $(3,5,6)$ regarding the potential of this crop in Puerto Rico, especially in areas of high rainfall (1600 to 2000 $\mathrm{mm} /$ year). Its high protein content, both of the pods and roots, the high resistance to most pests and diseases, and its ability to produce well under very adverse conditions, contrary to the behavior of most of the edible legumes, are among its outstanding characteristics. Moreover, the results showed the need for using wire supports if good pod yields are to be expected from high yielding cultivars such as WB 21-8. This will enable the plant to easily spread its leaves, exposing a larger surface area to sunlight for better photosynthetic activity. The fact that some cultivars bear edible tuberous roots, as well as the agronomic aspects of the crop, needs more intensive research.

The winged bean can be of importance in helping to overcome the world food shortage. Its high protein content could be important when diets are lacking in protein.

\section{RESUMEN}

Se realizó un experimento en un Ultisol (Torres) arcilloso para evaluar las cultivares de habichuelas aladas WB 21-8 y WB 10-3 y el efecto sobre su crecimiento, desarrollo, rendimiento de vainas verdes y de raíces comestibles, cultivadas con o sin soportes de alambre.

Los rendimientos de vainas verdes fueron consistentemente bajos en ambas cultivares cuando no se utilizaron soportes de alambre, probablemente debido a la pudrición de las vainas causada por la gran humedad del suelo que prevaleció durante el período de crecimiento, y por la escasa superficie foliar, que es tan esencial para la fotosíntesis.

Se usó un diseño de parcelas divididas con cuatro tratamientos repetidos cuatro veces en el que las cultivares fueron los tratamientos principales, y el uso o la omisión de soportes de alambre fueron los subtratamientos.

No hubo diferencias significativas entre las cultivares en al crecimiento y desarrollo, ni en el rendimiento de vainas verdes. Hubo, sin embargo, diferencias altamente significativas entre las cultivares cuando se utilizaron soportes de alambre. Hubo una diferencia significativa entre los subtratamientos de la cV. WB 21-8, pero no en los de la WB 10-3. La interacción entre cultivares y subtratamientos (soportes de alambre vs. no soportes) fue significativa al nivel de probabilidad de $5 \%$.

El contenido en proteína fue de $20 \%$, pero no hubo diferencias significativas que se puedan atribuir a los tratamientos. Observaciones después de cosechar el experimento revelaron la presencia de pequeñas raíces tuberosas con un gran número de nódulos. Aparentemente no existe gran diferencia en el rendimiento de raíces tuberosas entre las 
plantas (con o sin soportes de alambre). Estas contenían un 10\% de proteína (peso seco).

Estos resultados revelan el potencial de este cultivo en Puerto Rico, especialmente en aquellas zonas de alta precipitación. Su alto contenido proteínico en las vainas verdes y en las raices tuberosas, su alta resistencia a enfermedades y plagas, y su aptitud para producir altos rendimientos bajo condiciones muy adversas, contrario al comportamiento de la mayoría de las legumbres comestibles, son sus características de mayor importancia. Además, los resultados demostraron la necesidad de utilizar soportes de alambre para asegurar aitos rendimientos en variedades como la WB 21-8. La habichuela alada podría ser de importancia en el mejoramiento de los abastos nutricionales en el mundo actual.

\section{LITERATURE CITED}

1. Fox, R. H., Talleyrand, H., and Boulding, D. R., 1974. Nitrogen fertilization of fertilization of corn and sorghum grown in Oxisols and Ultisols in Puerto Rico. Agron. J. 66: $534-40$.

2. Harding, J., Lugo-López, M. A., and Pérez-Escolar, R., 1978. Promiscuous root nodulation of winged beans on an Oxisol in Puerto Rico, Trop. Agri. (Trinidad), Vol. 55 No. 4.

3. Martín, W. F. and Delpin, H. 1978. Vegetables for the hot humid tropics. I. The winged bean, Psophocarpus tetragonolobus, ARS. USDA.

4. Masefield, G. B., 1957. The nodulation of annual leguminous crops in Malaya, Empire J. Exp. Agri. 25 (98): 139-50.

5. Pérez-Escolar, R., Scott, T. W., and Lugo-López, M. A., 1978. Legume and nonlegume crop residues as sources of $\mathrm{N}$ in Oxisols and Ultisols, J. Agri. Univ. P. R. 62(4): 36i66.

6. The winged bean, a high protein crop for the tropics, 1975. Nat. Acad. Sci. 